\title{
Consequences of an Early PSA Response to Enzalutamide Treatment for Japanese Patients with Metastatic Castration-resistant Prostate Cancer
}

\author{
HARUO KATO, YOSUKE FURUYA, YOSHIYUKI MIYAZAWA, TAKESHI MIYAO, \\ TAKAHIRO SYUTO, MASASHI NOMURA, YOSHITAKA SEKINE, HIDEKAZU KOIKE, \\ HIROSHI MATSUI, YASUHIRO SHIBATA, KAZUTO ITO and KAZUHIRO SUZUKI \\ Department of Urology, Gunma University Graduate School of Medicine, Gunma, Japan
}

\begin{abstract}
Background/Aim: Recent studies have shown that an early prostate-specific antigen (PSA) response to androgen receptor (AR)-targeting agents in metastatic castration-resistant prostate cancer $(m C R P C)$ is associated with a better prognosis. We analyzed early PSA response to enzalutamide and oncological outcomes to study their prognostic significance in the Japanese population. Patients and Methods: Fifty-one patients with mCRPC (26 of predocetaxel and 25 of post-docetaxel status) were treated with enzalutamide. The PSA progression-free survival (PFS), radiographic PFS (rPFS) and overall survival (OS) were assessed. The association of rPFS and OS in patients with an early PSA response at 4 weeks after commencement of enzalutamide was studied. Results: Early PSA responses were significantly associated with a longer rPFS (median of 47.9 vs. 20.1 weeks, $p<0.001$, in patients exhibiting a 50\% PSA response; median of 40.9 vs. 20.1 weeks, $p=0.016$, in patients exhibiting a 30\% PSA response). OS was also significantly associated with an early PSA response ( $p=0.002$ for patients exhibiting a 50\% PSA response, $p=0.003$ for patients exhibiting a 30\% PSA response). Multivariate analysis showed that the predictors of a $50 \%$ PSA response were an interval to $m C R P C$ and a docetaxel treatment history, while the predictor of a $30 \%$ PSA response was a docetaxel treatment history. Furthermore, a 50\% PSA
\end{abstract}

This article is freely accessible online.

Correspondence to: Kazuhiro Suzuki, Professor and Chairman, Department of Urology, Gunma University Graduate School of Medicine, 3-39-22 Showa-machi, Maebashi, 371-8511, Gunma, Japan. Tel: +81 272208300, Fax: +81 272208318, e-mail: kazu@gunma-u.ac.jp

Key Words: Castration-resistant prostate cancer, enzalutamide, early PSA response, radiographic progression-free survival, overall survival. response was independently prognostic of rPFS. Conclusion: An early PSA response to enzalutamide was significantly associated with a longer rPFS and OS. This information will aid in the management of patients treated with enzalutamide.

The treatment strategies for metastatic castration-resistant prostate cancer (mCRPC) have changed dramatically in time since new androgen receptor (AR)-targeting agents and a new class of taxane agents have been approved in Japan (1). Enzalutamide and abiraterone acetate are AR-targeting agents with proven survival benefits in patients of both preand post-docetaxel status (2-5). Enzalutamide is a secondgeneration anti-androgen exerting multiple inhibitory functions on androgen signal transduction (6). The pivotal clinical trials PREVEIL and AFFIRM showed that use of these drugs was associated with significantly better overall survival (OS), radiographic progression-free survival (rPFS), prostate-specific antigen (PSA) PFS, quality-of-life as assessed by the Functional Assessment of Cancer TherapyProstate questionnaire (FACT-P) and skeletal-related events $(2,3,7,8)$. Useful clinical effects of enzalutamide have been reported in Japanese patients (9).

Generally, the responses to AR-targeting agents are categorized into three patterns: continuous sensitivity, resistance acquisition and primary resistance (10). The mechanisms underlying drug resistance are multifactorial and biomarkers of drug resistance against AR-targeting agents are very important in the selection of patients suitable for treatment with such agents (11). The $A R-V 7$ mutant, which lacks the ligand-binding domain of AR, has attracted attention in terms of resistance to AR-targeting agents (12). AR-V7 expression by circulating tumor cells (CTCs) was significantly associated with resistance to enzalutamide and abiraterone acetate $(13,14)$. However, no commercial method of detecting AR-V7 in CTCs is yet available. The prognostic significance of an early PSA response was recently evaluated in patients treated with AR-targeting 
agents, including abiraterone acetate and enzalutamide (1517). In the current study, we assessed PSA responses 4 weeks after initiation of enzalutamide in a Japanese population with mCRPC to determine whether such responses were associated with rPFS or OS.

\section{Patients and Methods}

Fifty-one patients with mCRPC treated with enzalutamide in Gunma University Hospital, Japan, from August 2014 through January 2015, were analyzed. The PSA levels, full blood counts and routine biochemical data were generally determined every 4 weeks, whereas radiographic analyses (computed tomography (CT)/bone scans) were generally performed every 3 to 5 months. Enzalutamide was basically discontinued after confirmation of radiographic progression, but not PSA progression, if no intolerable adverse events occurred. Docetaxel was administered with $70 \mathrm{mg} / \mathrm{m}^{2}$ dose every 4 weeks in combination with $10 \mathrm{mg}$ prednisolone or $1 \mathrm{mg}$ dexamethasone. PSA PFS and rPFS were calculated according to the definitions of the Prostate Cancer Working Group 2 (PCWG2) (18). OS was defined as the time to death or the last follow-up of surviving patients. Clinical data collected to the end of March 2016 were analyzed.

Patients' characteristics were compared using Student's $t$-test or the Chi-squared test. PSA PFS, rPFS and OS were estimated using the Kaplan-Meier method and statistical significance was assessed with the aid of the log-rank test. Univariate and multivariate analyses estimating the effects of pretreatment factors on rPFS and OS were performed using Cox's proportional hazard models. Factors predicting an early PSA response were evaluated using logistic regression models. Laboratory data, including hemoglobin, alkaline phosphatase (ALP), lactate dehydrogenase (LDH) and Creactive protein (CRP), were categorized in variables. Cut-off levels were determined by the median values of the aforementioned factors. SPSS software version 19 (IBM Corp., Armonk, NY, USA) was used in all analyses.

This study was approved by the institutional review board of Gunma University Hospital (No.1339).

\section{Results}

Patients' characteristics. Patients' characteristics are shown in Table I. The patients' ages ranged from 54 to 87 years (median=73). Most patients were of excellent performance status. All patients had radiographically confirmed metastases (bone only in $35.3 \%$, bone + lymph node in $25.5 \%$, lymph node only in $31.4 \%$ and viscera in $7.8 \%$ ). The time to mCRPC ranged from 4 to 157 months with a median of 20 months. Twenty-six patients were docetaxel-naïve and 25 were of postdocetaxel status. We first administered enzalutamide at $160 \mathrm{mg} /$ day with a dose reduction or interruption for patients who experienced intolerable adverse events. In the latter period of the study, we started with enzalutamide at $80 \mathrm{mg} /$ day and generally increased the dose to $160 \mathrm{mg}$ /day.

The post-docetaxel group was significantly younger, with their time to mCRPC being significantly shorter than that of patients in the pre-docetaxel group. In terms of the initial dose of enzalutamide, the rate of low-dose induction was significantly higher in the pre-docetaxel group. The PSA levels were significantly lower in the pre-docetaxel than post-docetaxel group. No significant difference was evident in the baseline hemoglobin, ALP, LDH or CRP levels.

PSA PFS, rPFS and OS. A waterfall plot of the best PSA response rate is shown in Figure 1. A 50\% PSA response was observed in $52.9 \%, 69.2 \%$ and $36.0 \%$ of patients in the entire, pre- and post-docetaxel groups, respectively. The PSA response in the pre-docetaxel group was significantly better than that in the post-docetaxel group $(p=0.024)$. The PSA PFS (according to the PCWG2) is shown in Table II. The median PSA PFS was 16, 24 and 12 weeks in the entire, preand post-docetaxel groups, respectively. The PSA PFS of the pre-docetaxel group was significantly longer than that of the post-docetaxel group ( $p=0.011)$. The median rPFS was 37.7, 51.6 and 29.4 weeks in the entire, pre- and post-docetaxel groups, respectively. The OS of the entire and pre-docetaxel groups did not attain the median, while the median OS of the post-docetaxel group was 63.7 weeks. The OS of the predocetaxel group was significantly longer than that of the post-docetaxel group $(p=0.004)$.

Early PSA response. Four weeks after initiation of treatment, a $30 \%$ and $50 \%$ PSA response was observed in $60.8 \%$ and $45.1 \%$ of patients, respectively, as shown in Table III. The pre-docetaxel group responded significantly better than did the post-docetaxel group ( $p=0.023$ for a $30 \%$ PSA response, $p=0.025$ for a $50 \%$ PSA response).

In all patients, $30 \%$ and $50 \%$ PSA responses at 4 weeks were significantly associated with a longer rPFS (median of 40.9 vs. 20.1 weeks, $p=0.016$, for those with a $30 \%$ PSA response; median of $47.9 v s .20 .1$ weeks, $p<0.001$, for those with a $50 \%$ PSA response) (Table IV; Figure 2a, b). OS was also significantly associated with $30 \%$ and $50 \%$ PSA responses at 4 weeks, with $p$-values of 0.003 and 0.002 , respectively (Table IV; Figure 3a, b).

In the pre-docetaxel group, a 50\% PSA response was significantly associated with a longer rPFS $(p=0.004)$, as shown in Table IV. In patients treated with docetaxel, a $30 \%$ PSA response at 4 weeks was significantly associated with a longer rPFS $(p=0.042)$. A 50\% PSA response at 4 weeks exhibited a strong tendency to be associated with a longer rPFS $(p=0.066)$ and OS $(p=0.096)$, as shown in Table IV.

Pretreatment factors predicting an early PSA response. Factors predictive of a $30 \%$ or $50 \%$ PSA response were estimated using logistic regression models. The tested variables were a history of docetaxel use; the enzalutamide dose; performance status; LDH, hemoglobin, ALP and CRP levels; and times to mCRPC of less than 12 or 16 months. A history of docetaxel use and a time to mCRPC of longer than 16 months significantly predicted a $50 \%$ PSA response. A 
Table I. Patients' characteristics.

\begin{tabular}{|c|c|c|c|c|c|}
\hline & & All patients & Pre-docetaxel & Post-docetaxel & $p$-Value \\
\hline Number & 51 & 26 & 25 & & \\
\hline Age (years) & Median (range) & $73(54-87)$ & $78(54-87)$ & $71(56-80)$ & 0.02 \\
\hline PSA (ng/ml) & Median (range) & $27.0(1.6-847.8)$ & $16.2(1.61-247.0)$ & $43.7(4.72-847.8)$ & 0.007 \\
\hline ECOG PS n $(\%)$ & $\begin{array}{c}0-1 \\
2\end{array}$ & $\begin{array}{c}46(90.2) \\
5(9.8)\end{array}$ & $\begin{array}{c}25(96.2) \\
1(3.8)\end{array}$ & $\begin{array}{c}21(84.0) \\
4(6.0)\end{array}$ & 0.69 \\
\hline Time to CRPC (months) & Median (range) & $20(4-157)$ & $31(4-157)$ & $18(5-150)$ & 0.009 \\
\hline Metastases & $\begin{array}{c}\text { Bone only } \\
\text { Bone + LN } \\
\text { Bone + Vis* } \\
\text { LN only } \\
\text { LN + lung }\end{array}$ & $\begin{aligned} 18 & (35.3) \\
13 & (25.5) \\
2 & (3.9) \\
16 & (31.4) \\
2 & (3.9)\end{aligned}$ & $\begin{array}{c}9(34.6) \\
5(19.2) \\
0 \\
11(42.3) \\
1(3.9)\end{array}$ & $\begin{array}{c}9(36.0) \\
8(32.0) \\
2(8.0) \\
5(20.0) \\
1(4.0)\end{array}$ & 0.295 \\
\hline \multicolumn{6}{|l|}{ Laboratory data ${ }^{\#}$} \\
\hline $\mathrm{Hb}$ & $\mathrm{g} / \mathrm{dl}$ & $12.4(6.5-14.9)$ & $12.6(8.1-14.9)$ & $11.8(6.5-14.2)$ & 0.122 \\
\hline ALP & $\mathrm{U} / 1$ & $272(119-1184)$ & $273(133-529)$ & $249(119-1184)$ & 0.258 \\
\hline $\mathrm{LDH}$ & $\mathrm{U} / 1$ & $221(107-1553)$ & $202.5(107-347)$ & $236(169-1553)$ & 0.097 \\
\hline CRP & $\mathrm{mg} / \mathrm{dl}$ & $0.11(0.0-9.66)$ & $0.1(0.0-4.0)$ & $0.16(0.01-9.66)$ & 0.086 \\
\hline \multirow[t]{2}{*}{ Docetaxel } & course & & & & \\
\hline & Median (range) & - & - & $11(1-33)$ & \\
\hline Initial dose & $160 \mathrm{mg}$ & $22(43.0)$ & $7(27.0)$ & $15(60.0)$ & 0.017 \\
\hline $\mathrm{n}(\%)$ & $80 \mathrm{mg}$ & $29(57.0)$ & $19(73.0)$ & $10(40.0)$ & \\
\hline
\end{tabular}

*One patient with lung and liver metastatis and the other patient with lung metastases. ${ }^{*}$ Laboratory data are expressed as median values with range. PSA, Prostate-specific antigen; CRPC, castration-resistant prostate cancer; ECOG PS, Eastren Cooperative Oncology Group performance status; $\mathrm{Hb}$, hemoglobin; LDH, lactate dehydrogenase; ALP, alkarine phosphatase; CRP, C-reactive protein; LN, lumph node; vis, viscera.

Table II. Median PSA PFS, rPFS and OS.

\begin{tabular}{lcccc}
\hline & All patients & Pre-docetaxel & Post-docetaxel & $p$-Value \\
\hline PSA PFS & & & & \\
$\quad$ Week & 16.0 & 24.0 & 12.0 & 0.011 \\
95\% CI & $11.7-20.3$ & $13.5-34.5$ & $7.6-16.4$ & \\
rPFS & & & & \\
$\quad$ Week & 37.7 & 51.6 & 29.4 & 0.76 \\
$\quad 95 \%$ CI & $31.9-43.6$ & $26.4-76.8$ & $11.2-47.6$ & \\
OS & & & & \\
$\quad$ Week & Not reached & Not reached & 63.7 & 0.004 \\
95\% CI & & & $32.4-95.0$ & \\
\hline
\end{tabular}

PSA PFS, Prostate-specific antigen progression free survival according to PCWG2 criteria; rPFS, radiographic progression-free survival; OS, overall survival; CI, confidence interval.

history of docetaxel use was a significant predictor of the $30 \%$ PSA response (Table I).

Prognostic factors for rPFS and OS. For rPFS, univariate analysis using Cox proportional hazard models showed that early PSA30\% response and 50\% response were significantly associated with better rPFS. Multivariate analysis showed that early $50 \%$ PSA response was independently predictive of rPFS (Table VI).
Table III. PSA responses at 4 weeks after treatment commencement.

\begin{tabular}{lcccc}
\hline & All patients & Pre-decetaxel & Post-docetaxel & $p$-Value \\
\hline $\begin{array}{l}30 \% \text { PSA } \\
\text { response } \\
\%\end{array}$ & & & & \\
$\begin{array}{l}50 \% \text { PSA } \\
\text { response } \\
\%\end{array}$ & $60.8 \%$ & $76.9 \%$ & $44.0 \%$ & 0.023 \\
\hline
\end{tabular}

PSA, Prostate-specific antigen.

For OS, univariate analysis showed that hemoglobin, ALP, CRP, time to CRPC with both 12 month and 16 month, a docetaxel treatment history, early PSA responses were significantly associated with better OS. Multivariate analysis showed that hemoglobin, ALP and a docetaxel treatment history were independently predictive of better OS (Table VII).

\section{Discussion}

The principal findings of the present study are the significant associations between the PSA responses 4 weeks after initiation of enzalutamide treatment and the improved 
Table IV. Median rPFS and OS in terms of early PSA responses.

\begin{tabular}{|c|c|c|c|c|}
\hline & PSA response & Responder & Non-responder & $p$-Value \\
\hline \multicolumn{5}{|l|}{ rPFS } \\
\hline \multirow[t]{2}{*}{ All patients } & $\begin{array}{c}30 \% \text { response } \\
\text { week }(95 \% \mathrm{CI})\end{array}$ & $40.9(35.2-46.5)$ & $20.1(13.8-28.5)$ & 0.016 \\
\hline & $\begin{array}{c}50 \% \text { response } \\
\text { week }(95 \% \mathrm{CI})\end{array}$ & $47.9(28.7-67.1)$ & $20.1(10.0-30.3)$ & $<0.001$ \\
\hline \multirow[t]{3}{*}{ Pre-docetaxel } & $30 \%$ response & & & \\
\hline & week $(95 \% \mathrm{CI})$ & $51.6(28.1-75.0)$ & $26.1(0-65.3)$ & 0.466 \\
\hline & $\begin{array}{c}50 \% \text { response } \\
\text { week }(95 \% \mathrm{CI})\end{array}$ & $64.3(35.4-93.2)$ & $23.4(11.9-34.9)$ & 0.004 \\
\hline \multirow[t]{3}{*}{ Post-docetaxel } & $30 \%$ response & & & \\
\hline & week $(95 \% \mathrm{CI})$ & $39.9(24.8-54.9)$ & $15.7(9.8-21.6)$ & 0.042 \\
\hline & $\begin{array}{c}50 \% \text { response } \\
\text { week }(95 \% \mathrm{CI})\end{array}$ & $40.9(35.4-46.3)$ & $15.7(13.8-17.6)$ & 0.066 \\
\hline \multicolumn{5}{|l|}{ OS } \\
\hline \multirow[t]{2}{*}{ All patients } & $\begin{array}{c}30 \% \text { response } \\
\text { week }(95 \% \mathrm{CI})\end{array}$ & not reached & $62.9(46.4-79.3)$ & 0.003 \\
\hline & $\begin{array}{l}50 \% \text { response } \\
\text { week }(95 \% \mathrm{CI})\end{array}$ & not reached & $63.7(38.2-89.3)$ & 0.002 \\
\hline \multirow[t]{3}{*}{ Pre-docetaxel } & $30 \%$ response & & & \\
\hline & week $(95 \% \mathrm{CI})$ & not reached & not reached & NA \\
\hline & $\begin{array}{c}50 \% \text { response } \\
\text { week }(95 \% \mathrm{CI})\end{array}$ & not reached & not reached & NA \\
\hline \multirow[t]{4}{*}{ Post-docetaxel } & $30 \%$ response & & & \\
\hline & week $(95 \% \mathrm{CI})$ & not reached & $50.3(38.5-62.1)$ & 0.122 \\
\hline & $50 \%$ response & & & \\
\hline & week $(95 \% \mathrm{CI})$ & not reached & $50.3(38.5-62.1)$ & 0.096 \\
\hline
\end{tabular}

PSA, Prostate-specific antigen; NA, not applicable; rPF, radiographic progression-free survival; CI, confidence interval; OS, overall survival.

oncological outcomes. Overall, both the 50\% and 30\% PSA responses strongly predicted both rPFS and OS. When patients were stratified by docetaxel treatment history, the 50\% PSA response still significantly affected rPFS and OS in patients without a history of docetaxel use. In patients of post-docetaxel status, such tendencies were consistently observed. Rescigno et al. (15) reported that a decline in the $30 \%$ PSA after 4 weeks of abiraterone acetate treatment was significantly associated with a better PFS and OS. Patients who did not achieve a 30\% PSA decline showed significantly poorer OS. In a clinical trial, Fuera et al. (16) showed that a $50 \%$ PSA decline after 4 weeks of treatment was significantly associated with a longer PFS and OS in patients on various AR-targeting therapies, including enzalutamide, abiraterone acetate and orteronel. The cohort of the Fuera's study included patients enrolled in clinical trials of cognate agents, with $78 \%$ being of post-docetaxel status. The authors confirmed the observations described above in patients treated with abiraterone acetate outside the clinical trial setting (16). A more recent study found that a very early PSA response (15 days after starting abiraterone acetate) was
Table V. Predictors estimating early PSA responses: multivariate analysis.

\begin{tabular}{lccc}
\hline & OR & $95 \%$ CI & $p$-Value \\
\hline $\begin{array}{l}30 \% \text { response } \\
\text { Decetaxel treatment } \\
\text { no } v s . \text { yes }\end{array}$ & 4.03 & $1.201-13.526$ & 0.024 \\
$\begin{array}{c}50 \% \text { response } \\
\text { Time to CRPC } \\
\quad \text { 16>mo } v s .<16 \mathrm{mo}\end{array}$ & 5.656 & $1.436-22.266$ & 0.013 \\
$\begin{array}{c}\text { Decetaxel treatment } \\
\text { no } v s . \text { yes }\end{array}$ & 3.588 & $1.002-12.747$ & 0.05 \\
\hline
\end{tabular}

PSA, Prostate-specific antigen; OR, odds ratio; CI, confidence interval; CRPC, castration-resistant prostate cancer.

significantly associated with a better PFS and OS (17). Based on these findings, our current study is the first to show that the early PSA response is significantly associated with PFS and OS in patients with enzalutamide cohort. 


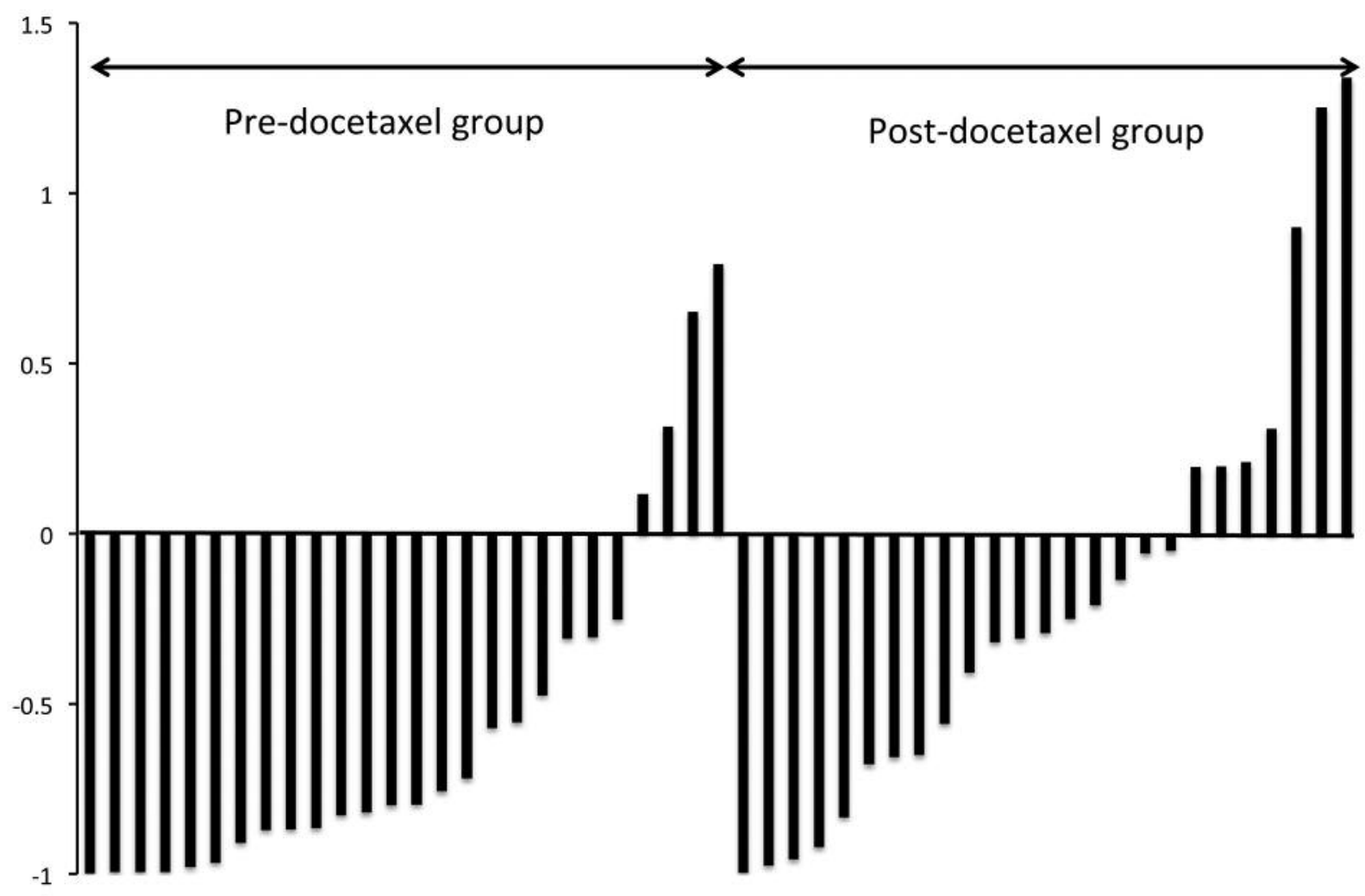

Figure 1. Waterfall plots showing the best responses in terms of changes in prostate-specific antigen (PSA) levels from baseline in patients treated with enzalutamide. Left panels: pre-docetaxel group. Right panels: post- docetaxel group. A 50\% PSA response was observed in $69.2 \%$ and $36.0 \%$ of patients in pre- and post-docetaxel groups, respectively $(p=0.024)$.

Identification of pretreatment biomarkers predicting the responses to AR-targeting agents would allow optimal use of such agents and taxanes. The responses to primary androgen deprivation therapy are considered to be key when estimating responses to subsequent CRPC treatment. Chi et al. (19) proposed that 12 months was the key time at which to evaluate responses to AR-targeting agents and recommended that patients showing shorter times to CRPC should be considered for upfront use of docetaxel. Sonpavde et al. (20) proposed that a time of 16 months to CRPC should trigger upfront use of chemotherapy (20). In our present study, a time of 16 months to mCRPC significantly predicted a $50 \%$ PSA response. Other factors, including the Gleason score and the TMPRSS2-ERG translocation, did not appear to estimate the response to abiraterone acetate $(21,22)$. The baseline testosterone level was reported to be significantly prognostic of OS, but did not predict the response to treatment (23). In our current study, the baseline hemoglobin and ALP levels were significantly associated with the prognosis of OS. One of the potential pretreatment prognostic factors is the AR-V7 expression level in CTCs (12-14). Although the cohort studied was small, Antonarakis et al. (13) reported that the
AR-V7 expression level in CTCs was prognostic of the outcomes of CRPC treatment. Further studies using liquid biopsies that include CTCs and cell-free DNA are warranted to establish robust biomarkers, which were cited in PCWG3 (24).

PSA flare is an important feature of an early change in the PSA level. The clinical significance of an early PSA rise has been characterized in patients treated with docetaxel. PSA flares occurred in $7.6 \%$ to $13.8 \%$ of patients and four courses of docetaxel were, at least, recommended (25). In terms of AR-targeting agents, PSA flare has been reported in patients treated with abiraterone acetate (26), but in less than $10 \%$ percent, and did not affect prognosis. Since AR-targeting agents affect AR action by ligand depletion or interference with signal transduction, a transient rise in PSA would be expected to be rare. Nelson (27) categorized prostate cancer cells into molecular states based on ligand-AR interactions. Enzalutamide and abiraterone acetate act in state II; the cancer cells undergo ligand depletion or interference with AR signal transduction. Eventually, the AR becomes activated by mutation, splicing variation or aberrant stimulation by cytokines (state III). We suggest that an early 

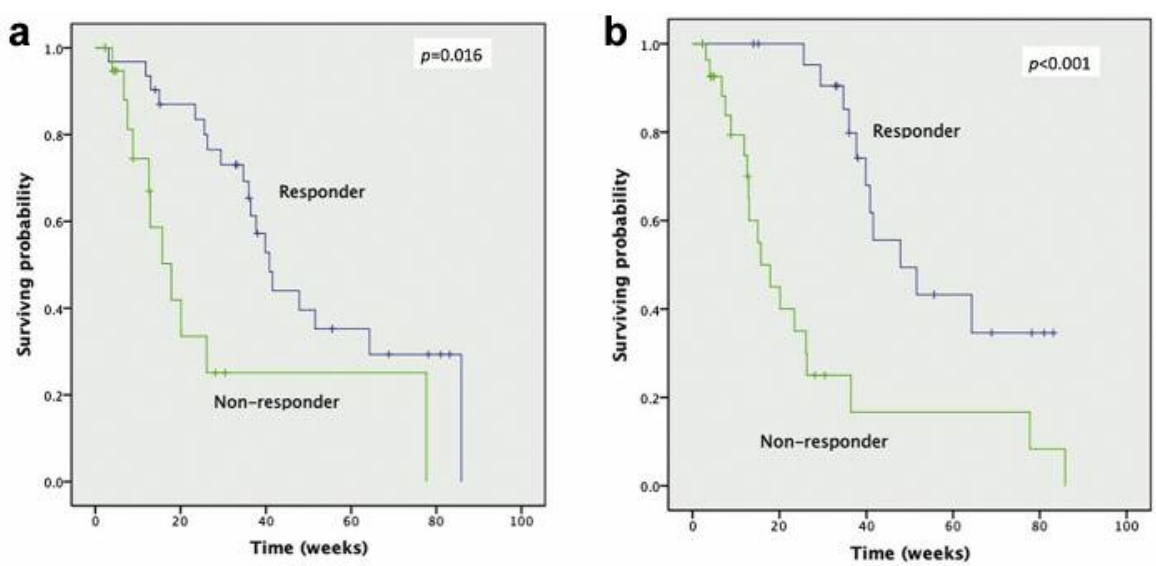

Figure 2. Radiographic progression-free survival of 51 patients treated with enzalutamide in terms of a (a) 30\% prostate-specific antigen (PSA) response and a (b) 50\% PSA response. Early PSA responder showed significantly better radiographic progression-free survival ( $p=0.016$ for $30 \%$ PSA response; $p<0.001$ for $50 \%$ PSA response).
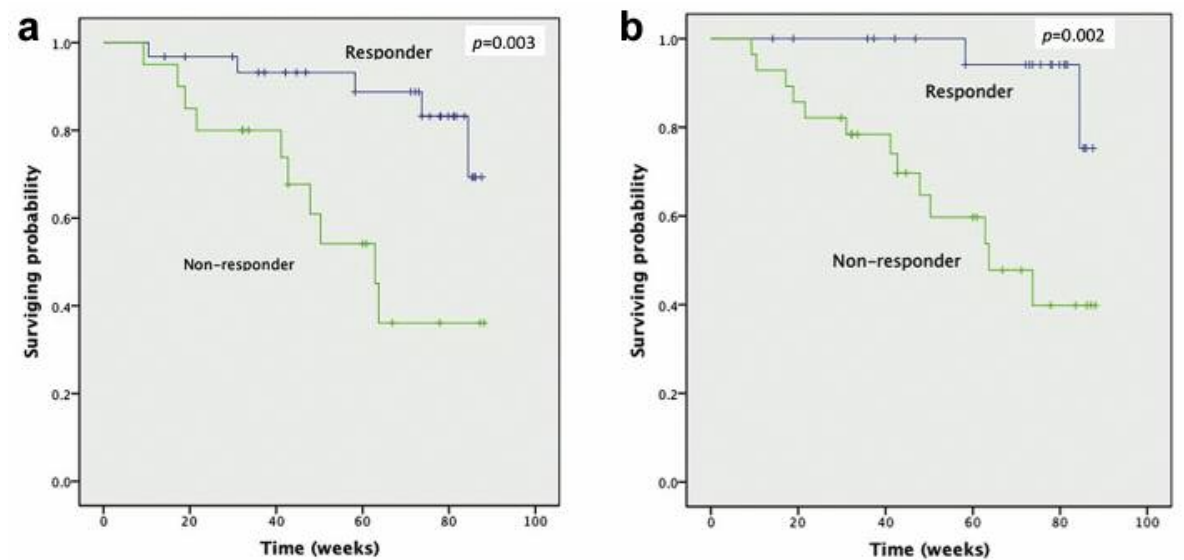

Figure 3. Overall survival of 51 patients treated with enzalutamide in terms of a (a) 30\% prostate-specific antigen (PSA) response and a (b) $50 \%$ PSA response. Early PSA responder showed significantly better overall survival ( $p=0.003$ for $30 \%$ PSA response; $p=0.002$ for $50 \%$ PSA response).

PSA response depends on the ratio of state II to state III cells. Further basic studies are required to prove this.

The labeled dose of enzalutamide is $160 \mathrm{mg} /$ day; we used 80 $\mathrm{mg} / \mathrm{day}$ at the start of treatment. Generally, the dose was rescheduled to $160 \mathrm{mg} /$ day within the first 1 to 2 months. As mentioned in the Result section, the initial dose did not significantly predict the early PSA response, rPFS or OS. Based on these findings, we analyzed all data of the current cohort. We are now exploring safety aspects in the same cohort.

Limitations of the present study include its retrospective nature and the small number of patients; the powers of analyses of groups stratified by docetaxel use are rather low. We also noticed that two different initial doses of enzalutamide were adopted in this cohort. Both univariate and multivariate analyses showed that initial doses were not predictive for rPFS or OS. In that sense, the clinical relevance in the current study would not be significantly affected by the initial doses of enzalutamide. However, an early PSA response was prognostically predictive in all patients treated with enzalutamide. The strong points of the study are the relatively uniform treatment strategy and follow-up featuring both regular PSA measurements and radiographic evaluation. Furthermore, this is the first report on the early PSA response in a Japanese mCRPC cohort treated with enzalutamide alone.

In conclusion, an early PSA response (4 weeks after initiation of enzalutamide) was significantly associated with a better rPFS and OS in a routine Japanese clinical setting. 
Table VI. Univariate and multivariate analysis for radiographic progression-free survival.

\begin{tabular}{|c|c|c|c|c|c|c|c|}
\hline \multirow[t]{2}{*}{ Variable } & & \multicolumn{3}{|c|}{ Univariate analysis } & \multicolumn{3}{|c|}{ Multivariate analysis } \\
\hline & & HR & $95 \% \mathrm{CI}$ & $p$-Value & HR & $95 \% \mathrm{CI}$ & $p$-Value \\
\hline ECOG PS & $1-2$ vs. 0 & 1.54 & $0.72-3.29$ & 0.27 & - & & \\
\hline $\mathrm{Hb}$ & $\leq 11.4 \mathrm{~g} / \mathrm{dL} v s .>11.4 \mathrm{~g} / \mathrm{dl}$ & 1397.0 & $0.65-2.98$ & 0.39 & - & & \\
\hline LDH & $\geq 221 \mathrm{U} / 1$ vs. $<221 \mathrm{U} / 1$ & 0.85 & $0.39-1.84$ & 0.8 & - & & \\
\hline ALP & $\geq 278 \mathrm{U} / 1$ vs. $<272 \mathrm{U} / 1$ & 1.58 & $0.74-3.38$ & 0.24 & - & & \\
\hline CRP & $\geq 0.11 \mathrm{mg} / \mathrm{dl} v s .<0.11 \mathrm{mg} / \mathrm{dl}$ & 1.6 & $0.75-3.44$ & 0.23 & - & & \\
\hline Time to CRPC & $\leq 12$ month $v s .>12$ month & 1.14 & $0.46-2.87$ & 0.78 & - & & \\
\hline Time to CRPC & $\leq 16$ month $v s .>16$ month & 1.45 & $0.65-3.21$ & 0.36 & - & & \\
\hline Dose & $160 \mathrm{mg} v s .80 \mathrm{mg}$ & 0.96 & $0.65-1.42$ & 0.85 & - & & \\
\hline Docetaxel treatment & yes $v s$. no & 1.97 & $0.92-4.24$ & 0.08 & - & & \\
\hline PSA $30 \%$ response & no vs. yes & 2.73 & $1.17-6.35$ & 0.02 & - & & \\
\hline PSA $50 \%$ response & no vs. yes & 3.98 & $1.79-8.88$ & 0.001 & 3.84 & $1.72-8.55$ & 0.001 \\
\hline
\end{tabular}

ECOG PS, Eastren Cooperative Oncology Group performance status; Hb,hemoglobin; LDH,lactate dehydrogenase; ALP, alkaline phosphatase; CRPC, castration-resistant prostate cancer; HR, hazard ratio; CI, confidence interval; CRP, C-reactive protein; PSA, prostate-specific antigen.

Table VII. Univariate and multivariate analysis for overall survival.

\begin{tabular}{|c|c|c|c|c|c|c|c|}
\hline \multirow[t]{2}{*}{ Variable } & & \multicolumn{3}{|c|}{ Univariate analysis } & \multicolumn{3}{|c|}{ Multivariate analysis } \\
\hline & & $\mathrm{HR}$ & $95 \% \mathrm{CI}$ & $p$-Value & $\mathrm{HR}$ & $95 \% \mathrm{CI}$ & $p$-Value \\
\hline ECOG PS & $1-2$ vs. 0 & 2.56 & $0.87-7.53$ & 0.087 & - & & \\
\hline $\mathrm{Hb}$ & $\leq 11.4 \mathrm{~g} / \mathrm{dl} v s .>11.4 \mathrm{~g} / \mathrm{dl}$ & 4.5 & $1.36-17.21$ & 0.015 & 8.72 & $1.52-50.07$ & 0.015 \\
\hline LDH & $\geq 221 \mathrm{U} / 1$ vs. $<221 \mathrm{U} / 1$ & 2.5 & $0.85-7.32$ & 0.095 & - & & \\
\hline ALP & $\geq 278 \mathrm{U} / 1$ vs. $<272 \mathrm{U} / 1$ & 3.19 & $1.09-9.36$ & 0.035 & 13.41 & $2.38-75.55$ & 0.003 \\
\hline CRP & $\geq 0.11 \mathrm{mg} / \mathrm{dl} v s .<0.11 \mathrm{mg} / \mathrm{dl}$ & 5.01 & $1.41-17.79$ & 0.013 & - & & \\
\hline Time to CRPC & $\leq 12$ month $v s .>12$ month & 4.91 & $1.73-13.92$ & 0.003 & - & & \\
\hline Time to CRPC & $\leq 16$ month $v s .>16$ month & 4.11 & $1.4-12.08$ & 0.01 & - & & \\
\hline Dose & $160 \mathrm{mg} v s .80 \mathrm{mg}$ & 1.1 & $0.64-1.88$ & 0.73 & - & & \\
\hline Docetaxel treatment & yes $v s$. no & 6.77 & $1.52-15.44$ & 0.012 & 5.87 & $1.11-31.19$ & 0.038 \\
\hline PSA $30 \%$ response & no $v s$. yes & 4.2 & $1.52-13.44$ & 0.07 & - & & \\
\hline PSA $50 \%$ response & no vs. yes & 7.82 & $1.75-34.95$ & 0.007 & - & & \\
\hline
\end{tabular}

ECOG PS, Eastren Cooperative Oncology Group performance status; Hb, hemoglobin; LDH, lactate dehydrogenase; ALP, alkaline phosphatase; CRPC, castration-resistant prostate cancer; HR, hazard ratio; CI, confidence interval; CRP, C-reactive protein; PSA, prostate-specific antigen.

These findings will aid in the optimal use of enzalutamide by Japanese patients.

\section{Conflicts of Interest}

Kazuhiro Suzuki has served as an advisory board member of, spoken for, and received a research grant from Astellas.

\section{References}

1 Fujimoto N: Novel agents for castration-resistant prostate cancer: early experience and beyond. Int J Urol 23(2): 114-121, 2016.
2 Beer TM, Armstrong DE, Rathkopf, Rathkopf DE, Loriot Y, Sternberg CN, Higano CS, Iversen P, Bhattacharya S, Carles J, Chowdhury S, Davis ID, de Bono JS, Evans CP, Fizazi K, Joshua AM, Kim CS, Kimura G, Mainwaring P, Mansbach H, Miller K, Noonberg SB, Scher HI, Taplin ME, Venner PM and Tombal B: Enzalutamide in metastatic prostate cancer before chemotherapy. N Engl J Med 371(5): 424-433, 2014.

3 Scher HI, Fizazi K, Saad F, Sasd F, Taplin ME, Sternburg CN, Miller K, de Wit R, Mulders P, Chi KN, Shore ND, Armstrong AJ, Flaig TW, Flechon A, Mainwaring P, Fleming M, Hainsworth JD, Hirmand M, Selby B, Seely L and de Bono JS: Increased survival with enzalutamide in prostate cancer after chemotherapy. N Engl J Med 367(13): 1187-1197, 2012. 
4 Ryan CJ, Smith MR, de Bono JS, Molina A, Logothetis CJ, de Souza P, Fizazi K, Mainwaring P, Piulats JM, Ng S, Carles J, Mulders PFA, Basch E, Small EJ, Saad F, Schrijvers D, Van Poppel H, Mukherjee SD, Suttamann H, Gerritsen WR, Flaig TW, George DJ, Yu EY, Efstathiou E, Pantuck A, Winquist E, Higano CS, Taplin ME, Park Y, Kheoh T, Griffin T, Scher HI and Rathkopf EE: Abiraterone in metastatic prostate cancer without previous chemotherapy. N Engl J Med 368(2): 138-148, 2013.

5 de Bono JS, Logothesis CJ, Molina A, Fizaz K, North S, Chu L, Chi KN, Jones R, Goodman Jr OB, Saad F, Staffurth JN, Mainwaring P, Harland S, Flaig TW, Hutson TE, Cheng T, Patterson H, Hainsworth JD, Ryan CJ, Sternberg CN, Ellard SL, Efstathiou E, Zivi A, Bianchini D, Loriot Y, Chieffo N, Kheoh T, Haqq $\mathrm{CH}$ and Scher HI: Abiraterone and increased survival in metastatic prostate cancer. N Engl J Med 364(21): 1995-2005, 2011.

6 Tran C, Ouk S, Clegg NJ, Chen Y, Watson PA, Arora V, Wongvipat J, Sitmith-Jones PM, Yoo D, Kwon A, Wasielewska T, Welsbie D, Chen CD, Higano CS, Beer TM, Hung DT, Scher HI, Jung ME and Sawyers CL: Development of a secondgeneration antiandrogen for treatment of advanced prostate cancer. Science 324(5928): 787-790, 2009.

7 Loriot Y, Miller K, Sternberg CN, Fizazi K, de Bono JS, Chowdhury S, Higano CS, Noonberg S, Holmstrom S, Mansbach H, Perabo FG, Phung D, Ivanescu C, Skaltsa K, Beer TM and Tombal B: Effect of enzalutamide on health-related quality of life, pain, and skeletal-related events in asymptomatic and minimally symptomatic, chemotherapy-naive patients with metastatic castration-resistant prostate cancer (PREVAIL): results from a randomised, phase 3 trial. Lancet Oncol 16(5): 509-521, 2015.

8 Fizazi K, Scher HI, Miller K, Basch E, Sternberg CN, Cella D, Forer D, Hirmand M and de Bono JS: Effect of enzalutamide on time to first skeletal-related event, pain, and quality of life in men with castration-resistant prostate cancer: results from the randomised, phase 3 AFFIRM trial. Lancet Oncol 15(10): 11471156, 2014.

9 Yamasaki M, Yuasa T, Yamamoto S, Hayashi T, Ogawa M, Sakura M, Masuda H, Fukui I and Yonese J: Efficacy and safety profile of enzalutamide for Japanese patients with castration-resistant prostate cancer. Anticancer Res 36(1): 361$365,2016$.

10 Mukherji D, Omlin A, Pezaro C, Shamseddine A and de Bono: Metastatic castration-resistant prostate cancer (CRPC): Preclinical and clinical evidence for the sequential use of novel therapeutics. Cancer Metastasis Rev 33(2-3): 555-566, 2014.

11 Watson PA, Arora VK and Sawyers CL: Emerging mechanisms of resistance to androgen receptor inhibitors in prostate cancer. Nat Rev Cancer 15(12): 701-711, 2015.

12 Watson PA, Chen YF, Balbas MD, Wongvipat J, Socci ND, Kim $\mathrm{K}$ and Sawyers CL: Constitutively active androgen receptor splice variants expressed in castration-resistant prostate cancer require full-length androgen receptor. Proc Natl Acad Sci USA 107(39): 16759-16765, 2010.

13 Antonarakis ES, Lu C, Wang H, Luber B, Nakazawa M, Roeser JC, Chen Y, Mohammad TA, Chen Y, Fedor HL, Lotan TL, Zheng Q, de Marzo AM, Isaacs JT, Isaacs WB, Nadal R, Paller CJ, Denmeade SR, Carducci MA, Eisenberger MA and Luo J: AR-V7 and resistance to enzalutamide and abiraterone in prostate cancer. N Engl J Med 371(11): 1028-1038, 2014.
14 Antonarakis ES, Lu C, Luber B, Wang H, Chen Y, Nakazawa M, Nadal Paller CJ, Denmeade SR, Cauducci MA, Eisenberger MA and Luo J: Androgen receptor splice variant 7 and efficacy of taxane chemotherapy in patients with metastatic castrationresistant prostate cancer. JAMA Oncol 1(5): 582-591, 2015.

15 Rescigno P, Lorente D, Bianchini D, Ferraldeschi R, Kolinsky MP, Sideris S, Zafeiriou Z, Sumanasuriya S, Smith AD, Mehra N, Jayaram A, Perez-Lopez R, Mateo J, Parker C, Dearnaley DP, Tunariu N, Reid A, Attard G and de Bono JS: Prostate-specific antigen decline after 4 weeks of treatment with abiraterone acetate and overall survival in patients with metastatic castration-resistant prostate cancer. Eur Urol 2016 Mar 7. pii: S0302-2838(16)00245-1. doi: 10.1016/j.eururo.2016.02.055. [Epub ahead of print] PubMed PMID: 26965561.

16 Fuerea A, Baciarello G, Patrikidou A, Albiges L, Massard C, Di Palma M, Escudier B, Fizazi K and Loriot Y: Early PSA response is an independent prognostic factor in patients with metastatic castration-resistant prostate cancer treated with nextgeneration androgen pathway inhibitors. Eur J Cancer 61: 44-51, 2016.

17 Facchini G, Caffo O, Ortega C, D’Aniello C, Di Napoli M, Cecere SC, Della Pepa C, Crispo A, Maines F, Ruatta F, Iovane G, Pisconti S, Montella M, Berretta M, Pignata S and Cavaliere C: Very early PSA response to abiraterone in mCRPC patients: A novel prognostic factor predicting overall survival. Front Pharmacol 2016 May 18;7:123. doi: 10.3389/fphar.2016.00123. eCollection 2016. PubMed PMID: 27242530.

18 Scher HI, Halabi S, Tannock I, Morris M, Sternberg CN, Carducci MA, Eisenberger MA, Higano C, Bubley GJ, Dreicer R, Petrylak D, Kantoff P, Basch E, Kelly WK, Figg WD, Small EJ, Beer TM, Widling G, Martin A and Hussain M: Prostate Cancer Clinical Trials Working Group. Design and end points of clinical trials for patients with progressive prostate cancer and castrate levels of testosterone: recommendations of the Prostate Cancer Clinical Trials Working Group. J Clin Oncol 26(7): 1148$1159,2008$.

19 Chi K, Hotte SJ, Joshua AM, North S, Wyatt AW, Collins LL and Saad F: Treatment of mCRPC in the AR-axis-targeted therapy-resistant state. Ann Oncol 26(10): 2044-2056, 2015.

20 Sonpavde G, Wang CG, Galsky MD, Oh WK and Armstrong AJ: Cytotoxic chemotherapy in the contemporary management of metastatic castration-resistant prostate cancer (mCRPC). BJU Int 116(1): 17-29, 2015.

21 Fizazi K, Flaig TW, Stockle M, Scher HI, de Bono JS, Rathkopf DE, Ryan CJ, Kheoh T, Li J, Todd MB, Griffin TW, Molina A and Ohlmann $\mathrm{CH}$ : Dose Gleason score at initial diagnosis predict efficacy of abiraterone acetate therapy in patients with metastatic castration-resistant prostate cancer? J Clin Oncol 27(4): 699-705, 2016.

22 Danila DC, Anand A, Sung CC, Heller G, Leversha MA, Cao L, Lilja H, Molina A, Sawyers CL, Fleisher M and Scherr MI: TMPRSS2-ERG status in circulating tumor cells as a predictive biomarker of sensitivity in castration-resistant prostate cancer patients treated with abiraterone acetate. Eur Urol 60(5): 897904, 2011.

23 Lyan CJ, Molina A, Li J, Kheoh T, Small EJ, Haqq CM, Grant RP, de Bono JS and Scher HI: Serum androgens as prognostic biomarkers in castration-resistant prostate cancer: Results from an analysis of a randomized phase III trial. J Clin Oncol 31(22): 2791-2798, 2013. 
24 Scher HI, Morris MJ, Stadler WM, Higano C, Basch E, Fizazi $\mathrm{K}$, Antonarakis ES, Beer TM, Carducci MA, Chi KN, Corn PG, de Bono JS, Dreicer R, George DJ, Heath EI, Hussain M, Kelly WK, Kiu G, Logothetis C, Nanus D, Sterin MN, Rathkopf DE, Sovin SF, Ryan CJ, Sartor O, Small EJ, Smith MR, Sternberg CN, Taplin ME, Wilding G, Nelson PS, Schwartz LH, Harabi S, Kantoff PW and Armstrong AJ: Trial design and objectives for castration-resistant prostate cancer: Updated recommendations from the Prostate Cancer Clinical Trials Working Group 3. J Clin Oncol 34(12): 1402-1418, 2016.

25 Nelius T and Filleur S: PSA surge/flare-up in patients with castration-refractory prostate cancer during the initial phase of chemotherapy. Prostate 69(16): 1802-1807, 2009.
26 Burgio SL, Conteduca V, Rudnas B, Carrozza F, Campadelli E, Bianchi E, Fabbri P, Montanari M, Carretta E, Menna C and de Giorgi U: PSA flare with abiraterone in patients with metastatic castration-resistant prostate cancer. Clin Genitourin Cancer 13(1): 39-43, 2015.

27 Nelson PS: Molecular states underlying androgen receptor activation: a framework for therapeutics targeting androgen signaling in prostate cancer. J Clin Oncol 30(6): 644-646, 2012.

Received August 9, 2016

Revised August 22, 2016

Accepted August 23, 2016 